\title{
Exposure to microplastics reduces attachment strength and alters the haemolymph proteome of blue mussels (Mytilus edulis $)^{\frac{13}{3}}$
}

\author{
Dannielle S. Green ${ }^{a, *}{ }^{*}$, Thomas J. Colgan ${ }^{\text {b, c }}$, Richard C. Thompson ${ }^{\text {, }}$, James C. Carolan ${ }^{\mathrm{e}}$ \\ a School of Life Sciences, Anglia Ruskin University, Cambridge, Cambridgeshire, CB11PT, United Kingdom \\ b School of Biological, Earth and Environmental Sciences, University College Cork, Cork, Ireland \\ ' School of Biological and Chemical Sciences, Queen Mary University of London, London, E14NS, United Kingdom \\ d School of Marine Science and Engineering, Plymouth University, Plymouth, Devon, PL48AA, United Kingdom \\ e Department of Biology, Maynooth University, Maynooth, Co. Kildare, Ireland
}

\section{A R T I C L E I N F O}

\section{Article history:}

Received 20 August 2018

Received in revised form 10 November 2018

Accepted 7 December 2018

Available online 10 December 2018

\section{Keywords:}

Biodegradable microplastics

Tenacity

Proteins

Polylactic acid

Polyethylene

Immunity

\begin{abstract}
A B S T R A C T
The contamination of marine ecosystems with microplastics, such as the polymer polyethylene, a commonly used component of single-use packaging, is of global concern. Although it has been suggested that biodegradable polymers, such as polylactic acid, may be used to replace some polyethylene packaging, little is known about their effects on marine organisms. Blue mussels, Mytilus edulis, have become a "model organism" for investigating the effects of microplastics in marine ecosystems. We show here that repeated exposure, over a period of 52 days in an outdoor mesocosm setting, of M. edulis to polyethylene microplastics reduced the number of byssal threads produced and the attachment strength (tenacity) by 50\%. Exposure to either type of microplastic altered the haemolymph proteome and, although a conserved response to microplastic exposure was observed, overall polyethylene resulted in more changes to protein abundances than polylactic acid. Many of the proteins affected are involved in vital biological processes, such as immune regulation, detoxification, metabolism and structural development. Our study highlights the utility of mass spectrometry-based proteomics to assess the health of key marine organisms and identifies the potential mechanisms by which microplastics, both conventional and biodegradable, could affect their ability to form and maintain reefs.
\end{abstract}

(c) 2018 Published by Elsevier Ltd.

\section{Introduction}

Microplastic particles $(0.1 \mu \mathrm{m}-5 \mathrm{~mm})$ are the most numerically abundant form of solid waste on Earth (Eriksen et al., 2014) and are a potential threat to marine ecosystems globally (Galloway et al., 2017). Global plastic production, which has risen from $\sim 1.5$ million metric tonnes (MTT) in 1950 to 335 MMT in 2016, is predicted to continue to rise (Plastics Europe, 2017). The majority (39.9\%) of this production is designed for use in single-use packaging, most of which is composed of polyethylene (PE) (Plastics Europe, 2017). Plastics that are able to biodegrade in composting facilities ("biodegradable"), however, have been proposed as suitable alternatives to conventional packagings, such as PE, and global production for these polymers is also growing (Bioplastics Europe,

\footnotetext{
This paper has been recommended for acceptance by Maria Cristina Fossi.

* Corresponding author.

E-mail address: dannielle.green@anglia.ac.uk (D.S. Green).

${ }^{1}$ Lead contact.
}

2016). Polylactic acid (PLA), derived from e.g. starch, accounts for $\sim 45 \%$ of the global market of biodegradable plastics and $\sim 60 \%$ of its production is used to make packaging (Markets and Markets, 2015). Most microplastics arise from the fragmentation of larger plastic litter items rather than being directly littered as micro-sized particles (for example, microbeads). Packaging items are also the most abundant form of coastal litter (Galgani et al., 2015) and are, therefore, likely the greatest source of microplastic litter.

Current estimates of environmental concentrations of microplastics in coastal waters are biased towards larger particles because the mesh sizes used to sample are generally $>330 \mu \mathrm{m}$. When a smaller mesh is used, however, estimates of concentrations in seawater have been found to be three orders of magnitude greater (e.g. from $\sim 0.005 \mathrm{~L}^{-1}$ with a $335 \mu \mathrm{m}$ net to up to $\sim 6 \mathrm{~L}^{-1}$ with grab samples filtered over a $0.45 \mu \mathrm{m}$ filter; Barrows et al., 2017). Given that global production of waste is not expected to peak before 2100 and that the amount of plastic in the marine environment is expected to increase by an order of magnitude by 2025 (Jambeck et al., 2015), abundances of microplastics, and their 
potential impacts on marine organisms, are likely to be even greater in the coming decades.

Understanding the impacts of microplastics is ongoing and has been the subject of several recent reviews (such as Galloway et al., 2017, de Sá et al., 2018 and Anbumani and Kakkar, 2018). Microplastics have been shown to negatively affect neural (neurotoxicity in nematodes; Lei et al., 2018), cellular (oxidative stress in leucocytes of gilthead seabream; Espinosa et al., 2018) to population level (reduced reproductive output of oysters; Sussarellu et al., 2016) biological processes and functions. One of the most well studied marine organisms with respect to microplastics, is the blue mussel, Mytilus edulis. M. edulis is an important ecosystem engineer, clinging together using byssal threads (extensible proteinaceous fibres; Waite, 1991) to form reefs, which are important biogenic habitats (Seed, 1996). They are filter feeders and have been found to ingest microplastics in natural (Van Cauwenberghe et al., 2015; De Witte et al., 2014) and experimental settings (Browne et al., 2008; von Moos et al., 2012). Despite this growing body of work, our understanding of how microplastics affect the general health of $M$. edulis, ranging from its biological activity to its underlying molecular phenotype, is currently lacking.

Haemolymph is the blood-plasma equivalent of the invertebrate circulatory system, involved in the transportation of oxygen, nutrients, as well as proteins involved in important biological processes, including the nervous system, reproduction and the immune system. Within molluscs, the haemolymph has been a well-studied medium for understanding the immune complement, as well as functionality, including aspects of both the cellular (Carballal et al., 1997) and humoral immune response (Campos et al., 2015). Directly assessing the cellular and molecular composition of haemolymph, particularly proteins, provides an insight into the general health of an invertebrate organism and can reveal the signatures of environmental stress (Brown et al., 2006; Hannam et al., 2010). Invertebrate haemolymph protein abundances may be assessed using enzyme assays, gel electrophoresis or directly using mass spectrometry-based proteomics, which results in the unbiased identification and quantification of multiple proteins in a given sample (e.g. Campos et al., 2015; McNamara et al., 2017). The increasing incorporation of -omics techniques within the study of key ecological species have improved our understanding of the immune complement (Campos et al., 2015; Wu et al., 2016), structural composition (Mann et al., 2012; Mann and Edsinger, 2014), biomarkers of disease and pollution (Wu et al., 2016; Campos et al., 2016) as well as responses of organisms to environmental change (Tomanek, 2012; Tomanek, 2014).

To date, the vast majority of experiments investigating detrimental effects of microplastics exposure have used highly controlled laboratory conditions, with very high concentrations of microplastics, for example 110 (Van Cauwenberghe et al., 2015) to $>1$ billion (Browne et al., 2008) particles $\mathrm{ml}^{-1}$, which do not simulate natural conditions of the habitats in which the organisms reside. Compared with indoor laboratories, outdoor mesocosm systems can provide a better understanding of environmentally relevant effects of contaminants on individuals, populations and communities (Miko et al., 2015). In order to estimate future risks, an outdoor mesocosm experiment was used to expose M. edulis to a relatively low concentration $\left(\sim 1\right.$ particle $\mathrm{mL}^{-1}$ or $\left.25 \mu \mathrm{g} \mathrm{L}^{-1}\right)$ of a range of particle sizes $(\sim 0.5-\sim 330 \mu \mathrm{m})$ of conventional (high-density polyethylene - HDPE) or biodegradable (polylactic acid - PLA) microplastics in a natural outdoor setting for 52 days to assess impacts on (i) important biological traits as ecosystem engineers including byssal thread production and attachment strength and (ii) underlying molecular health through proteomic analysis of their haemolymph.

\section{Methods}

\subsection{Experimental design and set-up}

Mesocosm experiments were set up at the outdoor flowthrough mesocosm facility at Queen's University Marine Laboratory, Portaferry, Northern Ireland. The experimental design consisted of one fixed factor "Plastic", with three levels: no microplastics added (control), polylactic acid (PLA) and high density polyethylene (HDPE).

Full details of the experimental set-up can be found in Green et al. (2017), but are described here in brief. Mesocosms were $10 \mathrm{~L}$ polypropylene buckets (height $\mathrm{x}$ diameter $=25 \times 25 \mathrm{~cm}$ ). The experiment had 5 replicates $(n=5, N=15)$ and to simulate the habitat where the mussels were collected from, each mesocosm contained a $5 \mathrm{~cm}$ layer of muddy sediment. On the 26th of August 2014, after allowing $48 \mathrm{~h}$ for the sediment to settle, each mesocosm received 7 individuals of $M$. edulis. Mussels were measured, weighed and randomly allocated to treatments in order to ensure that no biases due to size were introduced into the experiment. The average $( \pm$ S.E.M.) whole animal wet weight was $19.84 \pm 0.51 \mathrm{~g}$ and there were no differences among treatments (ANOVA: $F_{2,12}=0.18$, $\mathrm{P}=0.831)$. The average $( \pm$ S.E.M) length of the mussels was $48.17 \pm 0.83 \mathrm{~mm}$ and there were also no differences in length among treatments (ANOVA: $\mathrm{F}_{2,12}=0.87, \mathrm{P}=0.469$ ). The experiment ran for 52 consecutive days (until 14th October 2014). Sandfiltered seawater, sourced from Strangford Lough (54 $22^{\prime} 51.1^{\prime \prime} \mathrm{N}$; $5^{\circ} 33^{\prime} 04.0^{\prime \prime} \mathrm{W}$ ) was continuously provided to each mesocosm at constant flow rates $\left(\sim 500 \mathrm{~mL} \mathrm{~min}^{-1}\right)$ via individual hoses resulting in an overlying water column of $\sim 8 \mathrm{~L}$.

\subsection{Microalgal culture and microplastic dosing}

Cultures of the microalgae Isochrysis galbana were prepared using seawater ( $35 \mathrm{ps} \mu$ ), which was filtered with $0.45 \mu \mathrm{m}$ aperture membranes and sterilised with UV light. PLA or HDPE microplastics were then added to $5 \mathrm{~L}$ bottles with I. galbana and were continuously mixed with air bubblers. Fresh batches of control and microplastic-dosed I. galbana cultures were made weekly. Virgin (pre-production) white PLA and HDPE microplastic particles (fragments not spheres) used in the experiments had a volumeweighted mean diameter of $65.6 \mu \mathrm{m}$ (range $=0.6-363 \mu \mathrm{m})$ for PLA and $102.6 \mu \mathrm{m}$ (range $=0.48-316 \mu \mathrm{m}$ ) for HDPE. Every day, each mesocosm received $250 \mathrm{~mL}$ of $\sim 2 \times 10^{6}$ cells $\mathrm{mL}^{-1}$ of microalgae containing either 0 (control) or $800 \mu \mathrm{g} \mathrm{L}^{-1}$ of PLA or HDPE microplastics, equating to a concentration in the mesocosms of $25 \mu \mathrm{g} \mathrm{L}^{-1}$. This corresponds to approximately $1296.3( \pm 182.9)$ and 844.9 $\left( \pm 138.7\right.$ ) particles $L^{-1}$ respectively (Green et al., 2017). Although this is high relative to current environmental concentrations, due to the range of particle sizes included, these concentrations are among the lowest used experimentally to date and, therefore, among the most environmentally realistic (Lenz et al., 2016). In order to simulate a pulse of microplastics in the environment (such as from wastewater effluent), mussels were exposed for $2 \mathrm{~h}$ per day. During dosing, the flow of water was paused and air bubblers were used to keep the water moving and aerate the mesocosms. The water flow in the mesocosms was resumed after $2 \mathrm{~h}$ and fresh seawater replaced the microplastic-contaminated water which was captured for safe disposal.

\subsection{Tenacity of mussels}

The remaining individuals from each of the mesocosms (excluding those removed for filtration and proteomics measurements) were placed onto glass petri dishes in clean buckets with 
fresh flowing seawater. Feeding (without microplastics) was resumed for a further 3 days (in order to allow the mussels to attach their byssal threads) before tenacity was measured for one randomly selected mussel from each replicate mesocosm. Tenacity was measured following the method of Denny (1987). Briefly, a portable dynometer (Pesola, Sweden), scaled 0-10 N, was used to measure the maximal vertical force required for the individual to become dislodged (attachment strength, $\mathrm{N}$ ). The dynometer had a small clamp that gripped individual mussels. The maximum dislodgement force was marked by a ring on the dynamometer, which remained in place after detachment indicating the maximum extension of the spring (to the nearest $0.1 \mathrm{~N}$ ). Shell planform area $\left(\mathrm{A}_{\mathrm{pl}}\right)$ was approximated as an ellipse with shell height and width as major and minor axes (measured with vernier callipers to $1 \mathrm{~mm}$ ), respectively (Bell and Gosline, 1997). Tenacity was calculated as dislodgement force per unit mussel planform area, in $\mathrm{N} \mathrm{m}^{-2}$. The number of byssal threads deployed by each of the mussels used in tenacity measurements was also counted.

\subsection{Proteomic analysis of mussels}

After 50 days, haemolymph was extracted from one individual from each mesocosm. In order to minimise disturbance, exposure to the air was not longer than 3 min before haemolymph extraction. Prior to haemolymph extraction, the shells were temporarily opened $2-3 \mathrm{~mm}$ to allow for the removal of excess water from the interior. The shells were then allowed to reclose and form a tight seal. An Omnican $\mathrm{F}$ syringe with an integrated 30 gauge needle was inserted between the shells of the mussel into the posterior adductor muscle and haemolymph slowly collected. The syringe was then removed from the needle and the haemolymph was dispensed into a nuclease-free $1.5 \mathrm{~mL}$ microcentrifuge tube. The haemolymph was stored temporarily at $-20^{\circ} \mathrm{C}$ overnight before transfer to $-80^{\circ} \mathrm{C}$ for long-term storage. As haemocytes can be reactive to oxygen causing the production of melanin, we took additional care to remove haemocytes prior to sample preparation for mass-spectrometry.

$200 \mu \mathrm{l}$ crude haemolymph was removed and centrifuged at $8000 \times g$ for $5 \mathrm{~min}$ to pellet cellular debris. The supernatant was then removed, quantified and four independent biological replicates were analysed from each treatment: control $(n=4)$, PLA$(\mathrm{n}=4)$ and HDPE-exposed $(\mathrm{n}=4)$ mussels. $50 \mu \mathrm{g}$ of each sample was precipitated using the 2D Clean-Up Kit (GE HealthCare), following the manufacturer's instructions and the resulting protein pellet was resuspended in $50 \mu \mathrm{l} 6 \mathrm{M}$ urea, $2 \mathrm{M}$ thiourea, $0.1 \mathrm{M}$ Tris$\mathrm{HCl}, \mathrm{pH}$ 8.0.50 mM ammonium bicarbonate was added to each sample and proteins were reduced with $0.5 \mathrm{M}$ dithiothreitol (DTT) at $56{ }^{\circ} \mathrm{C}$ for $20 \mathrm{~min}$ and alkylated with $0.55 \mathrm{M}$ iodoacetamide (IAA) at room temperature for $15 \mathrm{~min}$, in the dark. $1 \mu \mathrm{l}$ of a $1 \% \mathrm{w} / \mathrm{v}$ solution of Protease Max Surfactant Trypsin Enhancer (Promega) and $0.5 \mu \mathrm{g}$ of Sequence Grade Trypsin (Promega) was added to give a protein:trypsin ratio of $100: 1$. The protein/trypsin mixture was incubated at $37^{\circ} \mathrm{C}$ for $18 \mathrm{~h}$. Digestion was terminated by adding $1 \mu \mathrm{l}$ of $100 \%$ trifluoroacetic acid (Sigma Aldrich) and incubation at room temperature for $5 \mathrm{~min}$. Samples were centrifuged for $10 \mathrm{~min}$ at $13,000 \times g$ and a volume equivalent to $40 \mu \mathrm{g}$ of pre-digested protein was removed and purified for mass spectrometry using C18 Spin Columns (Pierce), following the manufacturer's instructions. The eluted peptides were dried using a SpeedyVac concentrator (Thermo Scientific Savant DNA120) and resuspended in $2 \% \mathrm{v} / \mathrm{v}$ acetonitrile and $0.05 \% \mathrm{v} / \mathrm{v}$ trifluoroacetic acid (TFA). Samples were sonicated for $5 \mathrm{~min}$ to aid peptide resuspension followed by centrifugation for $5 \mathrm{~min}$ at $13,000 \times \mathrm{g}$. The supernatant was removed and used for mass spectrometry.

\subsection{Mass spectrometry}

$1 \mu \mathrm{g}$ of each digested sample was loaded onto a QExactive (ThermoFisher Scientific) high-resolution accurate mass spectrometer connected to a Dionex Ultimate 3000 (RSLCnano) chromatography system. The peptides were separated by a $4 \%-35 \%$ gradient of acetonitrile on a Biobasic C18 PicofritTM column (100 mm length, $75 \mathrm{~mm}$ ID), using a 55 min reverse-phase gradient at a flow rate of $250 \mathrm{~nL} \mathrm{~min}{ }^{-1}$. All data were acquired with the mass spectrometer (MS) operating in automatic data dependent switching mode. A full MS scan at 140,000 resolution and a scan range of $400-2000 \mathrm{~m} / \mathrm{z}$ were followed by an MS/MS scan, resolution 17,500 and a range of $200-2000 \mathrm{~m} / \mathrm{z}$, selecting the 10 most intense ions prior to MS/MS.

Protein identification and Label Free Quantification (LFQ) normalisation of MS/MS data were performed using MaxQuant v1.5.6.5 (http://www.maxquant.org) following the general procedures and settings outlined in Hubner et al. (2010). The Andromeda search algorithm (Cox et al., 2011) incorporated in the MaxQuant software was used to correlate MS/MS data against a predicted protein set generated from available RNA sequences for Mytilus edulis (Bioproject: PRJEA75259), Mytilus gallaprovinciallis (Bioproject: PRJNA167773) and nucleotide/protein sequences available for $M$. edulis and $M$. gallaprovinciallis from the National Centre for Biotechnology and Information (NCBI) repository (8305 entries, downloaded September 2017) including the predicted protein set derived from the M. gallaprovinciallis genome (Murgarella) et al., 2016) (Bioproject: PRJNA262617). A 6-frame translation was conducted on the RNA sequences for the transcriptome resources of Mytilus species and an open reading frame extraction was performed. CD-Hit (Huang et al., 2010) was utilized to remove redundant sequences that were similar by $98 \%$ and above. The final predicted proteome comprised 12,453 sequences and was used in mass spectrometry searches in addition to a contaminant sequence set provided by MaxQuant.

The following search parameters were used: first search peptide tolerance of $20 \mathrm{ppm}$, second search peptide tolerance $4.5 \mathrm{ppm}$ with cysteine carbamidomethylation as a fixed modification and $\mathrm{N}$ acetylation of protein and oxidation of methionine as variable modifications and a maximum of two missed cleavage sites allowed. False Discovery Rates (FDR) were set to 1\% for both peptides and proteins and the FDR was estimated following searches against a target-decoy database. LFQ intensities were calculated using the MaxLFQ algorithm (Cox et al., 2014) from razor and unique peptides with a minimum ratio count of two peptides across samples.

\subsection{Processing of proteomic data}

Perseus v.1.5.2.6 (www.maxquant.org/) was used for data processing and visualization. The data matrix was first filtered for the removal of contaminants, decoy peptide matches and peptides identified by site. To obtain annotations for all identified proteins a fasta file was generated for the post-filtered proteins using BioEdit (Hall, 1999) and BlastP searched using Blast2Go (version: 4.1.9; Conesa et al., 2005) against the NCBI non redundant database with the following search settings: number of blast hits: 20, high-scoring segment pair length cutoff: 33 , Blast expect value: $1.0 \mathrm{e}^{-5}$. These annotations were subsequently uploaded to Perseus. Normalised LFQ intensity values (quantitative measurement of protein abundance) were $\log _{2}$ transformed and each replicate was assigned to its corresponding sample $(n=4)$. Proteins not found in all 4 replicates of at least one treatment were removed from the analysis. A dataimputation step was conducted to replace non-detected values with values that simulate signals of lowest abundant proteins 
chosen randomly from a distribution specified by a downshift of 1.8 times the mean standard deviation (SD) of all measured values and a width of 0.3 times this SD. Volcano plots were generated in Perseus by plotting negative $\log \mathrm{p}$-values against $\log _{2}$ fold-change values for each protein to visualize two-fold changes in protein expression of the microplastic exposed mussels relative to the control mussels and microplastic exposed mussels to each other. LFQ intensity values for proteins deemed statistically significant (by ANOVA, see Statistical data analyses) were Z-score normalised and hierarchical clustering was generated in order to summarise the overall differences among treatments. Gene Ontology mapping and functional domain analysis were performed using Blast2GO (v.4.1.9). The mass spectrometry proteomics data have been deposited to the ProteomeXchange Consortium via the PRIDE (Vizcaíno et al., 2016) partner repository with the dataset identifier PXD011567.

\subsection{Statistical data analyses}

Analysis of variance (ANOVA) was done using the $\mathrm{R}$ environment ( $\mathrm{R}$ v3.1.3; $\mathrm{R}$ core team 2015) to test the null hypotheses that there would be no difference in the (i) tenacity (ii) number of byssal threads (with $\mathrm{n}=5$ ) and (iii) relative (post imputation) abundances of individual proteins (with $\mathrm{n}=4$ ). The data were screened for normality (q-q plots, and Shapiro-Wilk tests) and homogeneity of variance (Levene's test, using the car package; Fox and Weisberg, 2011) to ascertain assumptions for ANOVA. Pairwise comparisons were computed when the main test was significant. Statistical significance was assumed at $\alpha=0.05$. In order to explore the possible relationships between the effects of microplastics on protein expression and effects on the biological functioning of blue mussels, Pearson's R correlation coefficients were calculated.

PERMANOVA was performed on post imputation data to test the null hypothesis that the haemolymph proteomes (composition and relative abundances of all 216 identified proteins) of mussels exposed to PLA or HDPE microplastics or to no microplastics (controls) would not differ. Patterns of difference in the haemolymph proteomes were visualized with canonical analysis of principal coordinates based on Bray-Curtis resemblance matrices (using PRIMER V6.1.12 with PERMANOVA+).

\section{Results}

\subsection{Effects of microplastics exposure on biological functions of M. edulis}

After 52 days of exposure to microplastics, the tenacity was lower $\left(F_{2,12}=5.6, P=0.019\right)$ and there were fewer byssal threads $\left(\mathrm{F}_{2,12}=10.3, \mathrm{P}=0.002\right)$ produced by mussels exposed to HDPE microplastics compared with mussels exposed to PLA or to no microplastics (Fig. 1). Specifically, after exposure to HDPE, attachment strength of $M$. edulis was 23.0 times less compared to the controls, while it was $\sim 2.2$ times less compared with mussels exposed to PLA (Fig. 1a). Mirroring this, the number of byssal threads produced by mussels exposed to HDPE was $\sim 1.6$ times less compared to the controls and $\sim 1.8$ times less compared to those exposed to PLA (Fig. 1b). Across all treatments, there was a significant positive relationship between attachment strength and the number of byssal threads (Pearson's $\mathrm{r}=0.78, \mathrm{t}=4.46, \mathrm{P}<0.001$ ).

\subsection{Effects of microplastics on the haemolymph proteome of M. edulis}

High resolution quantitative mass spectrometry identified 2745 peptides, representing 216 high confidence proteins from M. edulis
(Table S1). The haemolymph proteome was significantly altered by microplastics ( $p s e u d o-\mathrm{F}_{2,9}=2.89, \mathrm{P}=0.001$ ), with those exposed to HDPE or to PLA having significantly different protein profiles compared to those not exposed to microplastics (HDPE vs Control: pseudo- $\mathrm{t}=1.91, \mathrm{P}=0.023$ and PLA vs Control: pseudo- $\mathrm{t}=1.48$, $\mathrm{P}=0.029$ ). The haemolymph proteome of mussels exposed to HDPE also differed to those exposed to PLA (HDPE vs PLA: pseudo$\mathrm{t}=1.67, \mathrm{P}=0.030$ ). This is illustrated by ordination using canonical analysis of principal coordinates (Fig. 2). Furthermore, 19\% of the haemolymph proteome ( 40 proteins) was significantly affected by exposure to microplastics, with the majority being expressed at greater abundances (Table 1) when microplastics were present, compared to the control.

Of the 40 statistically significant proteins, six were differentially expressed in mussels exposed to both types of microplastic compared with controls. A further 11 were differentially expressed only in those exposed to HDPE compared with controls and four were differentially expressed only in those exposed to PLA compared with controls. Nine proteins differed between HDPE and PLA while five proteins differed in expression between HDPEexposed and both PLA-exposed and control mussels (Table 1, Fig. 3). Post-hoc tests were unable to determine the differences in the remaining five proteins. Functional annotation through homology searches and gene ontology mapping assigned functional information for statistically significant differentially expressed proteins identifying proteins with putative roles in the immune system, metabolism and detoxification, as well proteins of unknown function (Table 1 ).

\subsubsection{Effects of microplastics exposure on the mussel immune complement}

Within the haemolymph of mussels exposed to microplastics, 11 putative immune-responsive proteins were differentially expressed. Exposure to HDPE resulted in increased abundance of four immune-responsive proteins, including a putative proinflammatory cytokine, macrophage migration inhibitory factor (HE609105.1), as well as three complement C1q domain-containing (C1qDC) proteins (FR715598.1; FR715581.1; HE609753.1) (Table 1, Fig. 4). One of these putative C1qDC proteins (FR715598.1) was also increased in mussels exposed to PLA in comparison to the control. In addition, both microplastics treatments increased the abundance of a fibrinogen-related protein (OPL33687.1). In contrast, a second fibrinogen-related protein (OPL32613.1) was reduced within both treatments in comparison to control. Six immune proteins were differentially expressed between mussels exposed to PLA compared with those exposed to HDPE. In comparison to PLA, exposure to HDPE resulted in increased abundance of a putative pore-forming apextrin-like protein (HQ709238.1), a galectin (AJQ21509.1), as well as a putative antimicrobial peptide, mytimycin precursor (AET85056.1). In contrast, PLA exposure increased the abundance of two C1qDC proteins (FR715612.1; HE609604.1) in comparison to HDPE.

\subsubsection{Effects of microplastics exposure on the abundance of metabolic proteins}

Seven putative metabolic proteins were differentially expressed in response to one or both microplastics treatments. HDPE exposure resulted in increased expression of a glyceraldehyde-3-phosphate dehydrogenase (GAEN01008281.1), an aminopeptidase (GAEN01005918.1) and a protein putatively involved in retinal metabolism, retinol dehydrogenase 1 (OPL33362.1) (Table 1, Fig. 4). Two putative metabolic enzymes, a putative aspartate cytoplasmic protein (HE662841.1) and phosphoglycerate kinase (GAEM01000061.1) were increased within mussels exposed to PLA in comparison to both control and HDPE 

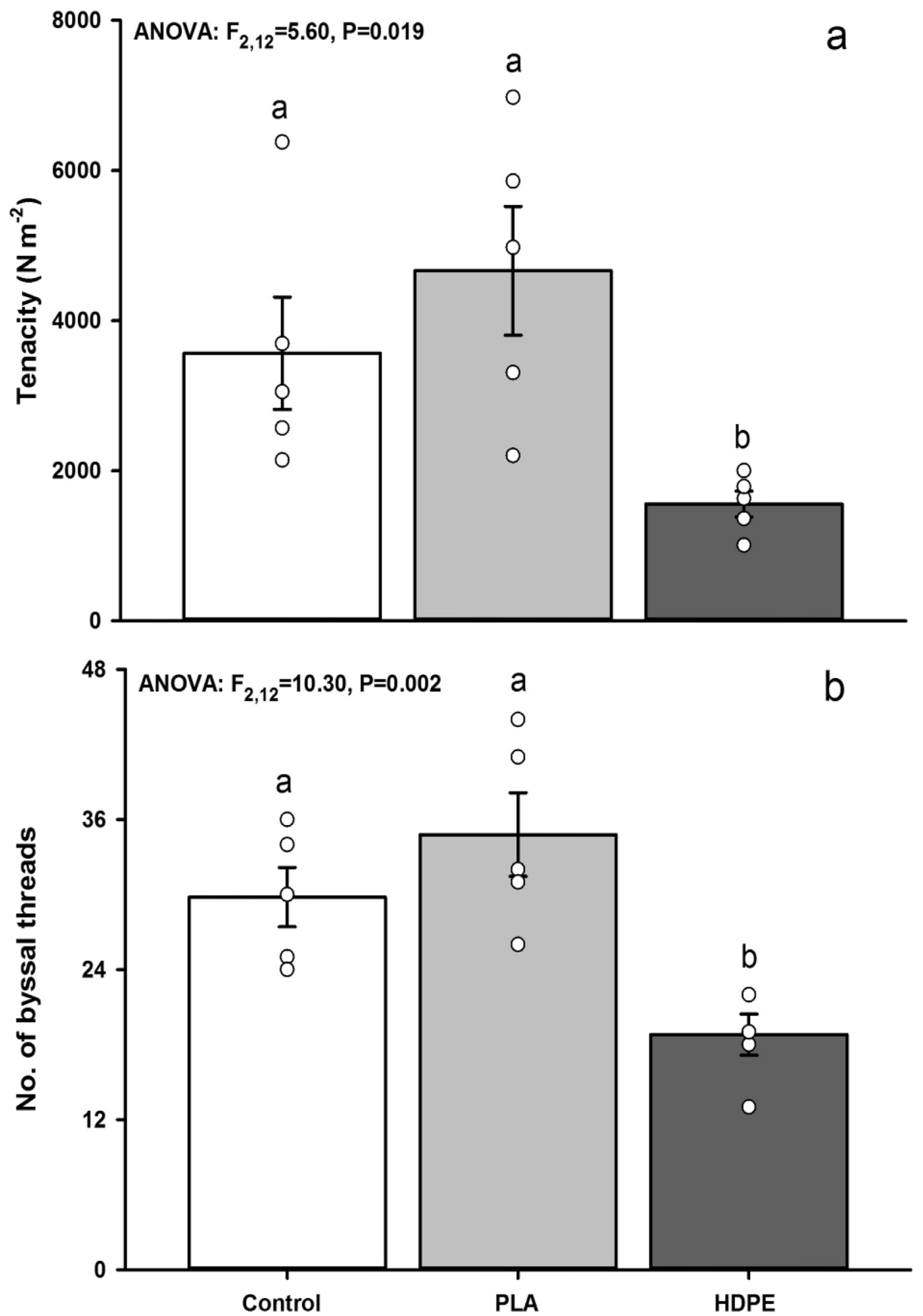

Fig. 1. Mean ( \pm S.E.M.) tenacity (a) and number of byssal threads (b) of M. edulis after 52 days of repeated exposure to $25 \mu \mathrm{g}$ L-1 of PLA (polylactic acid) or HDPE (high-density polyethylene), or no microplastics (control). Letters denote significantly different treatments determined by posthoc tests (Tukey's). 


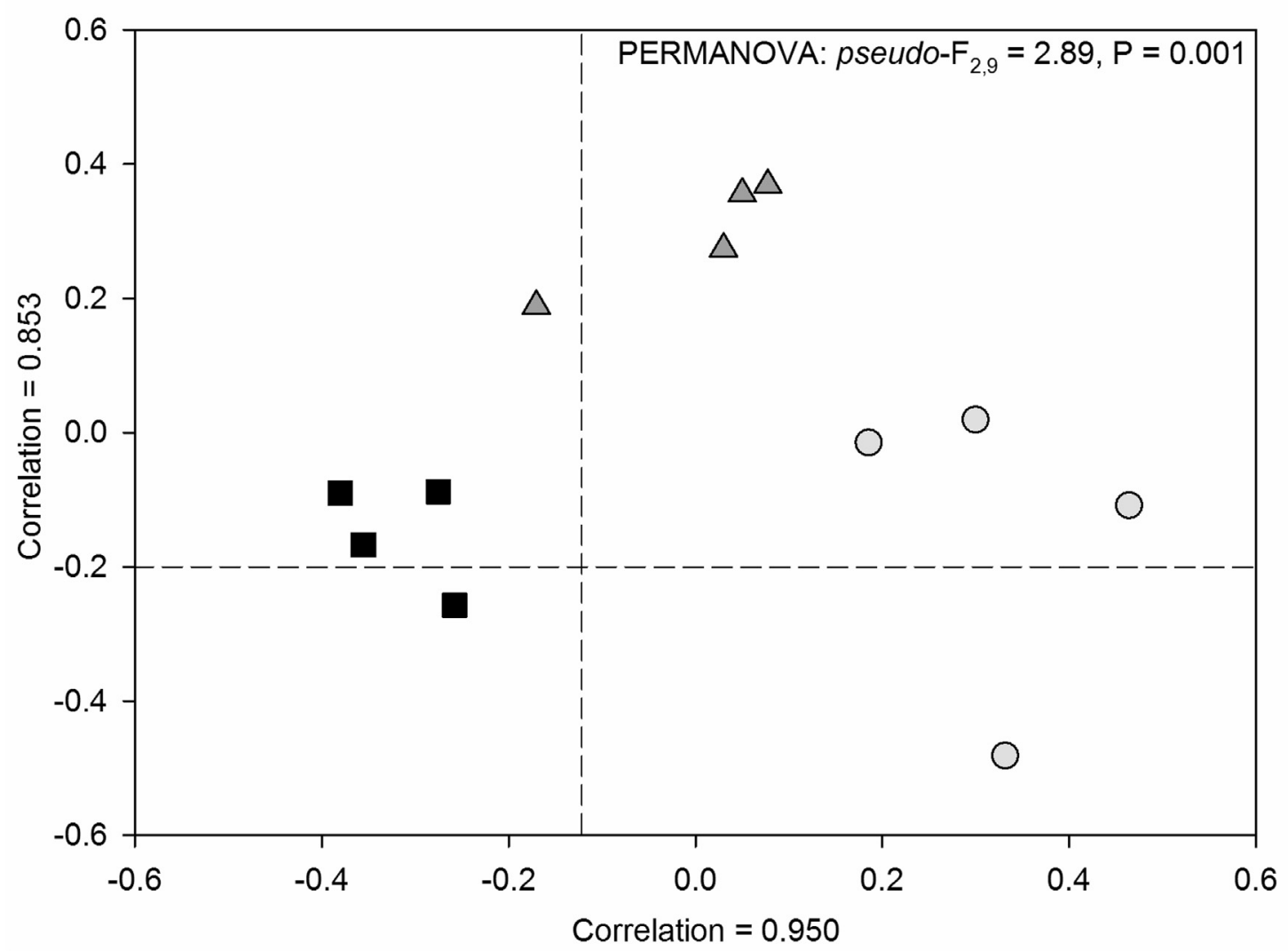

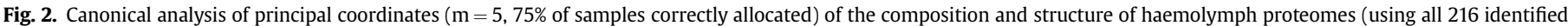

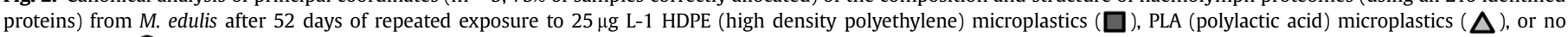
microplastics $(\mathcal{O})$.

individuals. PLA exposure also resulted in a reduction in a metalloproteinase inhibitor (GAEM01005782.1) in comparison to mussels exposed to HDPE. Both HDPE and PLA also led to an elevated abundance of a putative peptidyl-prolyl cis-trans isomerase protein (GAEN01009083.1) compared with control mussels.

\subsubsection{Potential detoxification proteins altered in response to microplastics exposure}

Four proteins previously identified to have putative roles as biomarkers of detoxification within molluscs were differentially expressed in response to microplastics exposure. Exposure to either microplastics treatment resulted in the increased expression of a putative heavy metal binding protein (HE609570.1) and putative detoxification enzyme, deferrochelatase peroxidase (GAEN01007747.1) in comparison to control mussels. Furthermore, a ferritin heavy oocyte (GAEN01007405.1) was increased in response to HDPE exposure in comparison to control mussels. A fourth protein, with a putative role in detoxification (cathepsin D; GAEM01006053.1), was also identified to be significantly affected by microplastics but post-hoc tests were not significant.

\subsubsection{Additional biomarkers associated with microplastics exposure}

Aside from variation in immune, metabolic and detoxification proteins, microplastics exposure changed the abundance of an additional 19 proteins. Both HDPE and PLA reduced the abundance of a protein of unknown function (OPL21291.1) compared with control mussels. Exposure to HDPE increased the expression of proteins involved in a variety of biological processes, including neurogenesis (GAEM01003123.1; OPL21044.1), structural integrity (GAEM01002086.1; GAEM01005782.1; OPL21594.1), DNA binding (CAD37821.1; CAC94907.1; GAEN01008605.1), and proteins of unknown function (OPL32817.1) in comparison to control and/or PLA treatment. In contrast, HDPE reduced the abundance of two proteins with roles in structural integrity (HE662833.1, GAEN01011200.1).

Exposure to PLA increased the expression of a putative growth factor protein (GAEN01008261.1) and a protein of unknown function (HE609843.1) in comparison to control and HDPEexposed individuals, respectively. One putative titin-like protein (GAEN01023435.1) was reduced within mussels exposed to PLA in comparison to control mussels. Post-hoc tests were unable to determine the direction of differences in four additional proteins found to be significantly affected, including proteins involved in structural integrity (GAEN01011004.1; GAEN01007066.1), translation (GAEN01008711.1) and a protein of unknown function (GAEN01005668.1).

\section{Discussion}

After long-term (52 days) exposure to $\sim 1$ particle $\mathrm{mL}^{-1}$ of HDPE microplastics, the number of byssal threads produced and the tenacity of $M$. edulis were reduced by approximately $50 \%$ when compared with mussels not exposed to microplastics. Tenacity is paramount to the ability of mussels to form and maintain reefs without being dislodged by hydrodynamic forces (Bell and Gosline, 1997). The ability to produce byssal threads and to form aggregations also increases fertilization success, makes mussels more 
Table 1

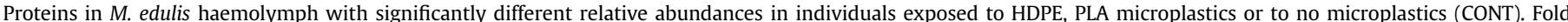

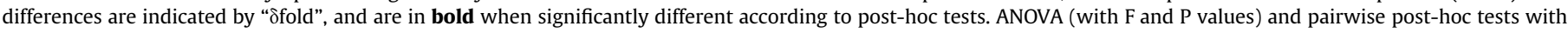
*indicating significant differences at $\mathrm{P}<0.05$ ). The source of the information on protein annotation is detailed in Table S2.

\begin{tabular}{|c|c|c|c|c|c|c|c|}
\hline & Protein ID & Protein Annotation & $\mathrm{F}$ & $\mathrm{P}$ & $\begin{array}{l}\delta \text { fold HDPE vs } \\
\text { CONT }\end{array}$ & $\begin{array}{l}\text { ¿fold PLA vs } \\
\text { CONT }\end{array}$ & $\begin{array}{l}\delta \text { fold HDPE vs } \\
\text { PLA }\end{array}$ \\
\hline \multirow[t]{11}{*}{ Immune } & FR715598.1 & C1Q Domain Containing 1Q19 & 80.2 & $<0.001$ & 7.0* & $5.4^{*}$ & 1.5 \\
\hline & HE609753.1 & Complement C1Q 4 & 58.0 & $<0.001$ & $4.2^{*}$ & -0.1 & $4.4^{*}$ \\
\hline & OPL33687.1 & Fibrinogen-Related & 8.0 & 0.009 & $3.7^{*}$ & $3.6^{*}$ & 0.1 \\
\hline & AJQ21509.1 & Galectin 2 & 6.7 & 0.016 & 0.7 & -0.5 & $1.2^{*}$ \\
\hline & HQ709238.1 & Apextrin & 5.6 & 0.026 & 1.9 & -0.9 & $2.8^{*}$ \\
\hline & FR715612.1 & C1Q Domain Containing 1Q33 & 5.5 & 0.027 & 2.3 & -1.5 & $3.8^{*}$ \\
\hline & HE609604.1 & Complement C1Q 2 & 5.1 & 0.032 & -2.8 & 1.3 & $-4.1^{*}$ \\
\hline & FR715581.1 & Complement C1Q Tumor Necrosis Factor & 4.7 & 0.039 & $3.8^{*}$ & 2.6 & 1.1 \\
\hline & HE609105.1 & Macrophage Migration Inhibitory Factor & 4.5 & 0.045 & $0.8^{*}$ & 0.3 & 0.5 \\
\hline & AET85056.1 & Mytimycin precursor & 4.3 & 0.049 & 1.9 & -3.3 & $5.1^{*}$ \\
\hline & OPL32613.1 & Microfibril-Associated Glyco 4 & 39.3 & $<0.001$ & $-4.0^{*}$ & $-5.2^{*}$ & 1.3 \\
\hline \multirow[t]{7}{*}{ Metabolism } & GAEN01005918.1 & Aminopeptidase $\mathrm{N}$ & 24.6 & $<0.001$ & $3.3^{*}$ & 0.6 & $2.7^{*}$ \\
\hline & HE662841.1 & Aspartate Cytoplasmic & 9.0 & 0.007 & 0.0 & $0.7^{*}$ & $-0.7^{*}$ \\
\hline & GAEN01009083.1 & Peptidyl-Prolyl Cis-Trans Isomerase & 6.8 & 0.016 & $0.6^{*}$ & $0.5^{*}$ & 0.1 \\
\hline & GAEN01008281.1 & Glyceraldehyde-3-Phosphate Dehydrogenase & 6.3 & 0.020 & $0.5^{*}$ & 0.4 & 0.2 \\
\hline & GAEM01005782.1 & Metallo Ase Inhibitor 3 & 5.4 & 0.029 & 1.5 & -0.5 & $2.0^{*}$ \\
\hline & GAEM01000061.1 & Phosphoglycerate Kinase & 4.9 & 0.037 & 0.3 & $0.6^{*}$ & -0.3 \\
\hline & GAEM01005782.1 & Retinal Dehydrogenase 1 & 5.8 & 0.024 & $1.9^{*}$ & 1.4 & 0.5 \\
\hline \multirow[t]{7}{*}{ Structural } & GAEM01002086.1 & Shell -5 & 12.5 & 0.002 & $2.8^{*}$ & 1.2 & 1.6 \\
\hline & HE662833.1 & Calponin -1 & 6.4 & 0.019 & $-3.1^{*}$ & -1.8 & -1.3 \\
\hline & GAEN01011200.1 & Myosin Essential Light Chain & 6.1 & 0.021 & $-1.2^{*}$ & -0.8 & -0.4 \\
\hline & OPL21594.1 & Singed Isoform X3 & 4.8 & 0.038 & $0.6^{*}$ & 0.5 & 0.2 \\
\hline & GAEN01011004.1 & Myosin Heavy Non-Muscle-Like & 4.6 & 0.043 & 2.1 & 2.0 & 0.1 \\
\hline & GAEN01023435.1 & Titin-Like & 4.5 & 0.045 & -0.5 & $-0.7^{*}$ & 0.2 \\
\hline & GAEN01007066.1 & $\begin{array}{l}\text { Myosin Regulatory Light Chain Smooth Adductor Muscle-Like } \\
\text { Isoform X3 }\end{array}$ & 4.4 & 0.047 & -1.3 & -1.1 & -0.2 \\
\hline \multirow[t]{4}{*}{ Detoxification } & HE609570.1 & Heavy Metal-Binding Protein & 10.5 & 0.004 & $4.4^{*}$ & $2.9^{*}$ & 1.5 \\
\hline & GAEN01007747.1 & Probable Deferrochelatase Peroxidase & 7.2 & 0.013 & $2.3^{*}$ & $2.5^{*}$ & -0.2 \\
\hline & GAEM01006053.1 & Cathepsin D & 4.6 & 0.042 & 2.2 & 2.2 & 0.0 \\
\hline & GAEN01007405.1 & Ferritin Heavy Oocyte Isoform & 4.8 & 0.038 & $2.3^{*}$ & 1.7 & 0.6 \\
\hline \multirow[t]{3}{*}{ DNA binding } & CAD37821.1 & Histone $\mathrm{H} 2 \mathrm{~A}$ & 8.3 & 0.009 & $2.9^{*}$ & -1.0 & $3.9^{*}$ \\
\hline & GAEN01008605.1 & Cytoplasmic A3A & 6.8 & 0.016 & $0.8^{*}$ & 0.7 & 0.2 \\
\hline & CAC94907.1 & Histone $\mathrm{H} 1$ & 4.4 & 0.046 & 0.8* & 0.2 & 0.5 \\
\hline Translation & GAEN01008711.1 & 60S Ribosomal L7 & 4.3 & 0.047 & -1.5 & -0.2 & -1.4 \\
\hline \multirow[t]{7}{*}{ Unknown } & OPL21291.1 & Hypothetical Protein Am593_06205 & 8.8 & 0.007 & $-0.9^{*}$ & $-0.8^{*}$ & -0.2 \\
\hline & HE609843.1 & Alpha-Crystallin A Chai & 5.2 & 0.031 & -0.9 & 0.3 & - 1.1 $^{*}$ \\
\hline & OPL32817.1 & Hypothetical Protein Am593_04753 & 4.6 & 0.041 & 1.1 & -2.1 & $3.1^{*}$ \\
\hline & GAEN01005668.1 & Hypothetical Protein Brafldraft_84721 & 4.3 & 0.048 & 1.1 & 1.0 & 0.2 \\
\hline & GAEM01003123.1 & Fatty Acid-Binding Brain & 58.6 & $<0.001$ & $4.7^{*}$ & -0.1 & $4.8^{*}$ \\
\hline & GAEN01008261.1 & Hypothetical Conserved 327 & 7.3 & 0.013 & 1.0 & $3.0^{*}$ & -2.0 \\
\hline & OPL21044.1 & Atrial Natriuretic Peptide Receptor A & 12.7 & 0.002 & $4.9^{*}$ & 1.2 & $3.7^{*}$ \\
\hline
\end{tabular}

resistant to predation and, overall, increases the probability of their survival (Christensen et al., 2015). Weakened attachment strength in response to conventional microplastics could, therefore, result in cascading ecological (by reducing the habitat availability for intertidal communities that depend on mussel reefs) and economic (by reducing yields of suspension culturing of mussels in aquaculture) consequences. For example, the mussel aquaculture industry is already worth $\sim 3-4$ billion USD globally per year (FAO, 2015) and is expected to grow in the coming decades. Reductions in the tenacity of two similar species of mussel, Mytilus trossulus (O'Donnell et al., 2013) and Mytilus coruscus (Zhao et al., 2017) have also been found in response to ocean acidification. Given that the concentrations of microplastics in the oceans (Jambeck et al., 2015) and the acidity of seawater (IPCC, 2014) are both likely to increase in the coming decades, future research should assess their combined effect on the health and tenacity of mussels.

In order to complement the measures of tenacity and to provide a detailed assessment of mussel health in response to microplastics exposure, we assessed changes in the proteome of the mussel haemolymph. We chose the haemolymph because it plays an important role as a crucial transporter of nutrients and oxygen, as well as being a primary site of immune activity and xenobiotic detoxification (Malagoli et al., 2007). Information regarding the effects of microplastic exposure on an organism's proteome are limited, but Sussarellu et al. (2016) found that exposure to polystyrene microplastics altered proteins in the oocytes of oysters and that this corresponded to a reduction in fertility. In the current study, exposure to HDPE or PLA microplastics resulted in complex changes in a number of key biological processes, including immunity, metabolism and detoxification.

Exposure of mussels to either PLA or HDPE microplastics resulted in changes in the immunological profiles of their haemolymph. The immune system represents an important obstacle to infection and disease, and has been extensively studied and characterised in mussels (Campos et al., 2015; Wu et al., 2016) and while interactions between microplastics and aspects of the mussel cellular immune response have been previously documented (von Moos et al., 2012; Avio et al., 2015; Paul-Pont et al., 2016), here we provide evidence of changes within the humoral components of the mussel haemolymph in response to microplastics exposure. 


\section{HDPE vs. Control PLA vs. Control}

\section{(A)}

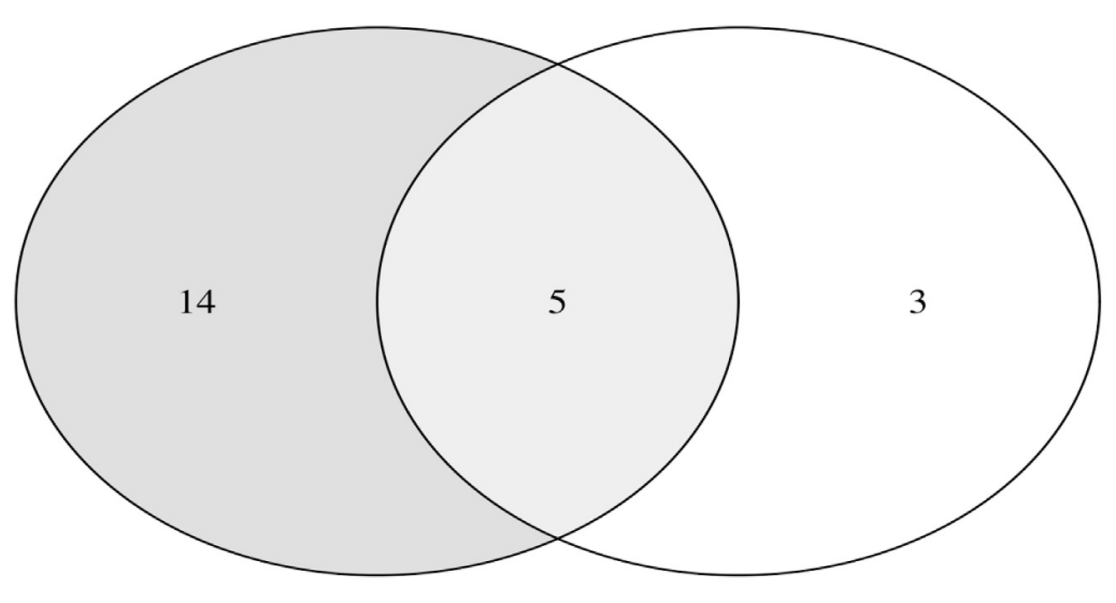

\section{HDPE vs. Control PLA vs. Control}

(B)

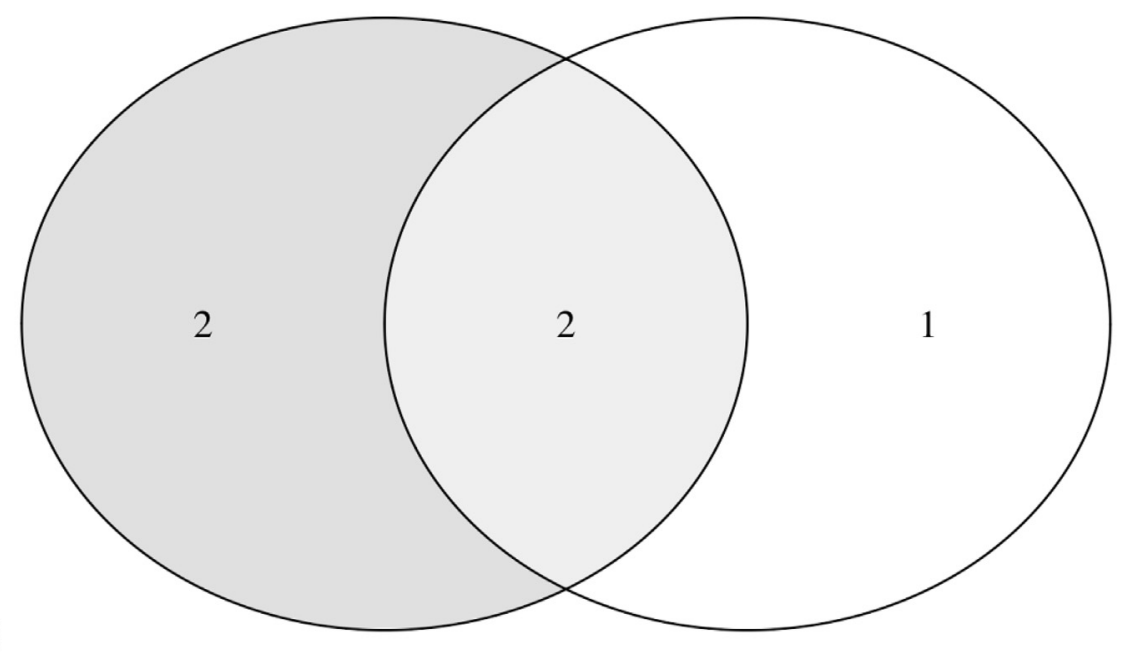

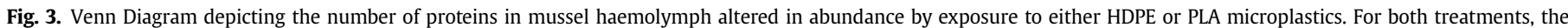
number of proteins with $\mathrm{A}$ ) increased expression, or B) decreased expression relative to control treatment is shown.

Specifically, members of the C1qDC protein family were affected by exposure to microplastics. C1qDC genes function in pathogen recognition (Gerdol et al., 2011) with certain genes elevated in response to bacterial challenge (Gestal et al., 2010). Additionally, two pathogen recognition molecules, galectin-2 and apextrin were upregulated in mussels exposed to HDPE compared with PLA microplastics. Within molluscs, galectin-2 and apextrin have been characterised to promote phagocytosis (Vasta et al., 2015) and function in membrane pore formation (Estevez-Calvar et al., 2011) respectively. Other effector molecules altered by microplastics exposure, included an increase in the antimicrobial peptide, myticin (Mitta et al., 1999), while fibrinogen-related proteins, functional in antigen recognition (Romero et al., 2011), were either up- or down-regulated in response to microplastics exposure. These immunological changes may be due to physical abrasion from the microplastics after being ingested by the mussels. Previous research by Avio et al. (2015) on a similar species of mussel to those used in the current study, Mytilus galloprovincialis, found similar immunological responses to virgin and contaminated microplastics (polyethylene and polystyrene) thus suggesting physical abrasion as the cause of response. It is possible that microplastics can translocate into tissues such as the gills and digestive tract (von Moos et al., 2012; Avio et al., 2015; Paul-Pont et al., 2016), as well as the haemolymph (Browne et al., 2008; Avio et al., 2015). Although microplastics in the haemolymph were not quantified in the present study, it is possible that physical abrasion of the tissue may have triggered the observed immunological responses but further research is required.

Despite some differences in the effects of PLA and HDPE on the proteome, a number of proteins responded similarly to both types of microplastic including complement $\mathrm{C} 1 \mathrm{q}$ domain-containing proteins (discussed above) and detoxification proteins, such as a peroxidase and a heavy metal-binding protein. Aside from direct immunological activity, immune-responsive proteins within the haemolymph may have roles in detoxification. Within Mytilus species, Cq1DC protein expression has been identified to change in response to heavy metal exposure suggesting a role in detoxification (Liu et al., 2014). Within the present study, a heavy metal binding protein, which contained a complement-like domain, was increased in response to both types of microplastics, indicating a 
A

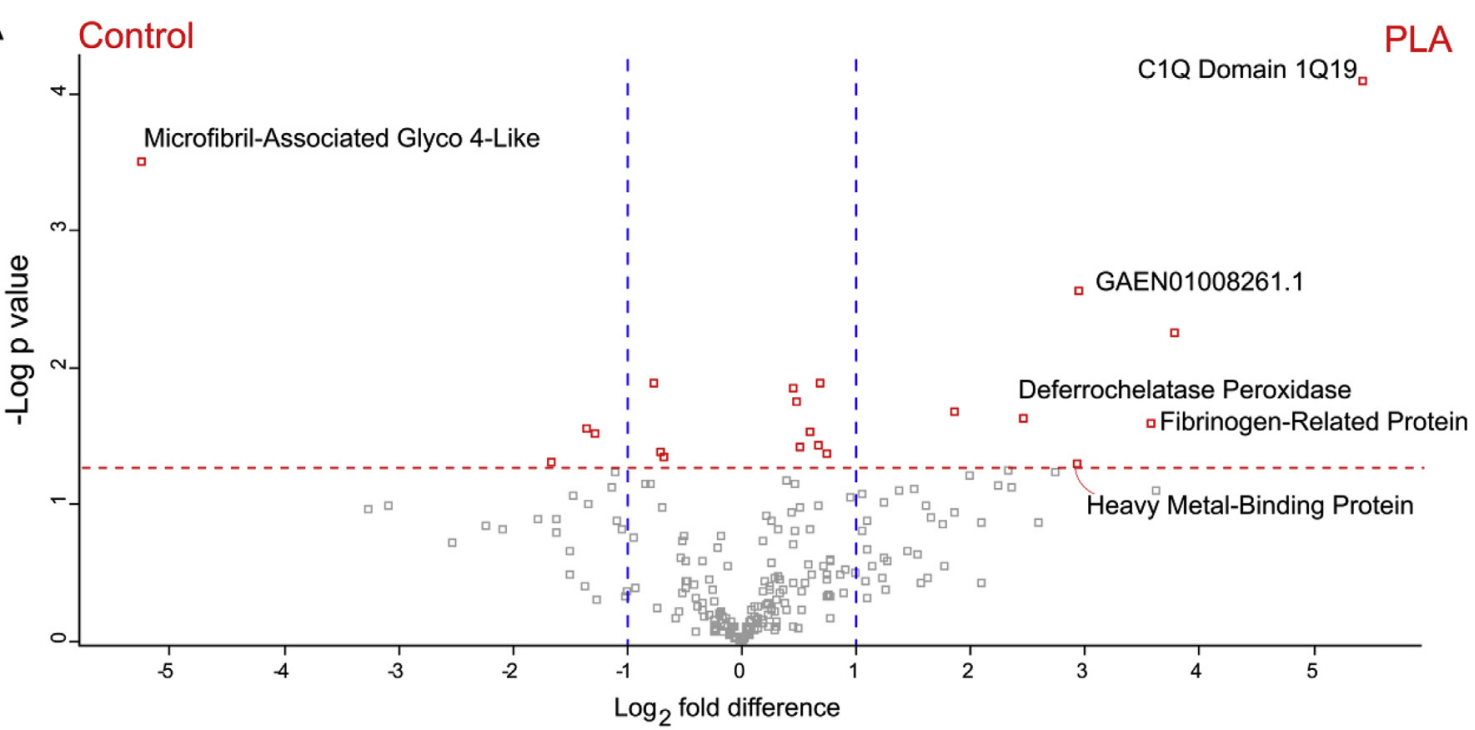

B

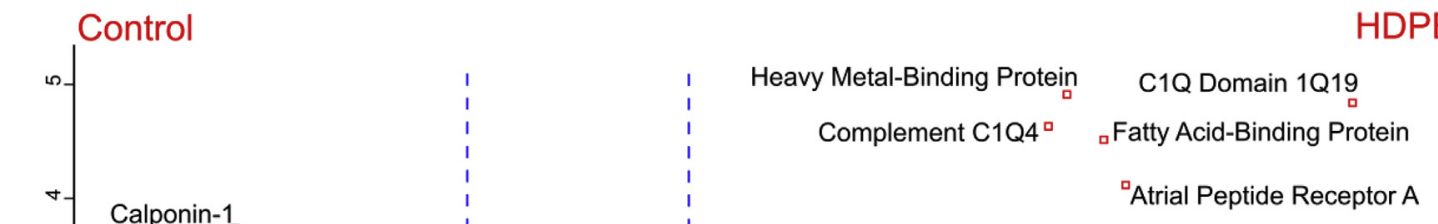

${ }_{\square}$ Aminopeptidase $\mathrm{N}$

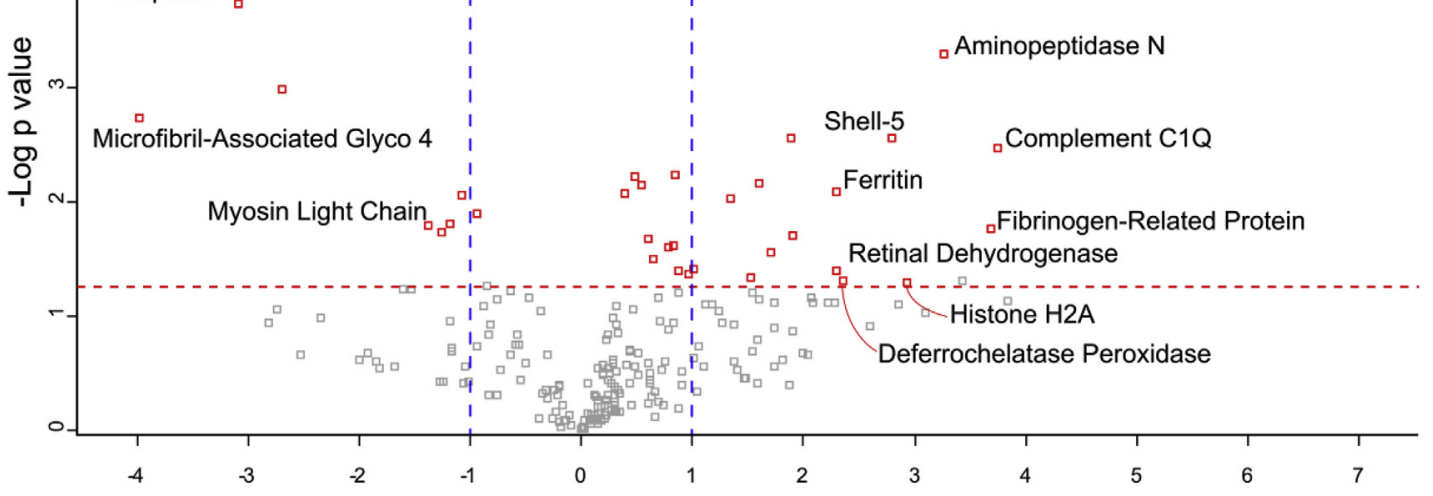

C $\log _{2}$ fold difference

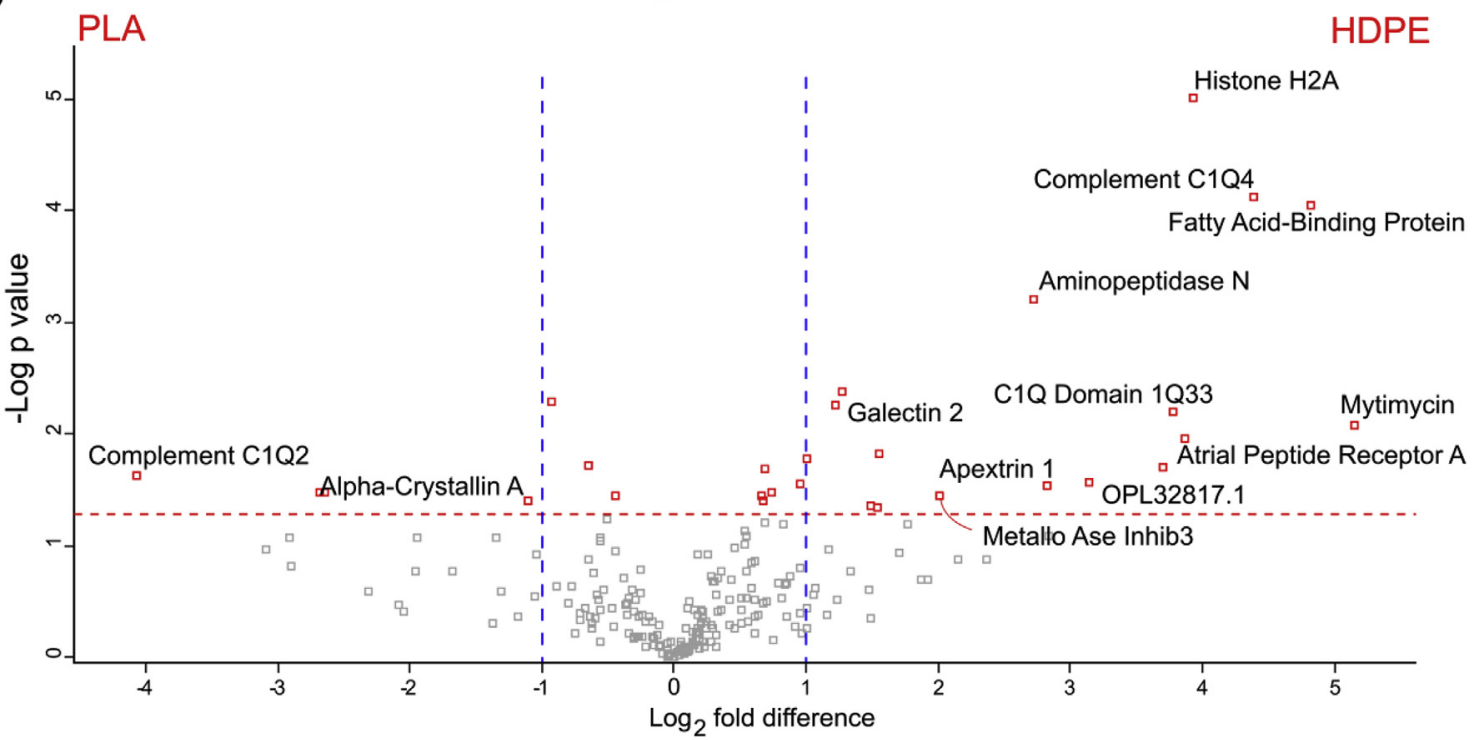

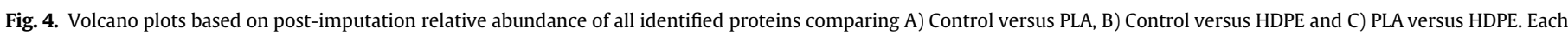

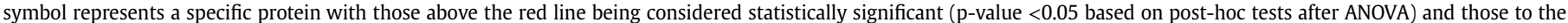

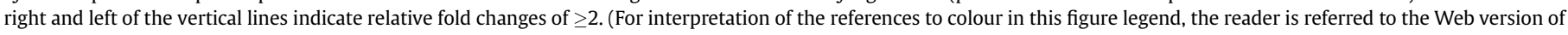
this article.) 
potential conserved biomarker of microplastics exposure. Heavy metal-binding proteins with strong reactivity to metal pollutants have been previously characterised within the mussel haemolymph (Renwrantz and Werner, 2007). While organisms require metal ions in trace amounts, excessive quantities can be toxic (Mejáre and Bülow, 2001) and require removal. Changes in immune proteins, as well as metal binding proteins, have been characterised previously in mussels in response to other pollutants, highlighting the role of the immune response as an indicator of a stressed phenotype (Coles et al., 1995). The ability of mussels to detoxify microplastics and associated by-products has been investigated through the measurement of detoxification enzyme activity (Paul-Pont et al., 2016), transcriptional responses in antioxidant genes (Avio et al., 2015), as well as the assessment of oxidative damage within exposed individuals (von Moos et al., 2012; Paul-Pont et al., 2016). We identified one such detoxification enzyme, a peroxidase, to be increased within both microplastic treatments. Peroxidases are vital enzymes involved in the degradation of by-products of respiration (Brigelius-Flohé and Maiorino, 2013) and have been identified to have increased enzyme activity within mussels in response to exposure to other pollutants (Vidal-Liñán et al., 2015) and within the marine copepod, Paracyclopina nana, in response to microplastics (Jeong et al., 2017). While the exact role of this peroxidase within Mytilus is unknown (Tomanek, 2015), it has previously been found to change in abundance in response to fluctuations in temperature, which suggests a role in oxidative stress (Fields et al., 2012). The generation of immune and detoxification defenses can be metabolically costly, placing additional demands on a stressed host. Within mussels, exposure to microplastics can affect metabolic enzymes, involved in essential processes, such as energy metabolism and respiration. For example, metabolic enzymes involved in glycolysis have been found to increase in response to microplastics exposure, which has been suggested to be associated with mounting a detoxification response (Paul-Pont et al., 2016). In the current experiment, the filtration rates of $M$. edulis were reduced by exposure to either HDPE or PLA microplastics, compared with controls (results reported in Green et al., 2017). Other contaminants can also cause similar responses, for example, in response to anthracene, Mediterranean clams (Ruditapes decussatus) also had reduced filtration rates and altered proteomes (Sellami et al., 2015). The reduction in the abundance of metabolic proteins may, therefore, be associated with reduced feeding but further research is needed to establish this causal link.

Myosin was reduced within mussels exposed to HDPE compared with controls. Myosin is involved in generating muscle contraction in bivalves (Yamada et al., 2000) and has been found to be altered by exposure to silver nanoparticles in a related mussel, M. galloprovincialis (Gomes et al., 2013). The deficiency in myosin, coupled with the expression of immune and detoxification proteins associated with mussels exposed to HDPE microplastics, may have contributed to less byssal threads being secreted. The tenacity of mussels is primarily related to byssal threads, either based on the number of threads or to their thickness (Carrington, 2002). The byssus proteome of another marine mussel of the same genus, $M$. coruscus, has been previously characterised and a selection of other structural proteins (collagen-like) were identified (Qin et al., 2016) and suggested to provide adjustable tension allowing for stable attachment within dynamic rocky intertidal environments (Qin and Waite, 1995).

Within the present study, exposure to conventional microplastics, HDPE, as well as a biodegradable alternative, PLA, resulted in changes to the haemolymph proteome, including proteins associated with stressed phenotypes. Certain proteins involved in immunity and detoxification, affected by both microplastics, provide candidate biomarkers for further research. Overall HDPE alone resulted in more proteomic changes in comparison to PLA. Despite being less severe, the effects of PLA microplastics on the proteome of $M$. edulis provides additional support to the growing body of literature on the potential issues of biodegradable alternatives. For example, PLA microplastics have also been found to reduce the biodiversity and abundance of organisms in marine invertebrate communities (Green, 2016) and to decrease the biomass of benthic primary producers (Green et al., 2017; Green et al., 2016). Biodegradable plastics are set to become more dominant as packaging in the future, possibly replacing some conventional plastics (Markets and Markets, 2015). They are, therefore, also more likely to become litter. Current testing methods, even those developed specifically for marine habitats (ASTM D7991-15), are limited in their ability to predict the break-down and ecological impacts of biodegradable plastics in the real world (Bioplastics Europe, 2016). Multidisciplinary research combining molecular, ecophysiological and traditional ecological techniques is recommended in order to gain a more holistic understanding of the potential impacts of conventional and biodegradable polymers.

\section{Acknowledgements}

Thank you to Dr Bas Boots for helpful comments on this manuscript and to the staff of Portaferry Marine Laboratory for facilitating this research. This research was funded by the Irish Research Council with a Postdoctoral Research Project Grant (GOIPD/2013/306) awarded to DSG. The Maynooth University QExactive Quantitative Mass Spectrometer was funded under the SFI Research Infrastructure Call 2012; Grant Number: 12/RI/2346 (3).

\section{Appendix A. Supplementary data}

Supplementary data to this article can be found online at https://doi.org/10.1016/j.envpol.2018.12.017.

\section{References}

Anbumani, S., Kakkar, P., 2018. Ecotoxicological effects of microplastics on biota: a review. Environ. Sci. Pollut. Control Ser. 25, 14373.

Avio, C.G., Gorbi, S., Milan, M., Benedetti, M., Fattorini, D., d'Errico, G., Pauletto, M. Bargelloni, L., Regoli, F., 2015. Pollutants bioavailability and toxicological risk from microplastics to marine mussels. Environ. Pollut. 198, 211-222.

Barrows, A.P.W., Neumann, C.A., Berger, M.L., Shaw, S.D., 2017. Grab vs. neuston tow net: a microplastic sampling performance comparison and possible advances in the field. Anal. Method. 9 (9), 1446-1453.

Bell, E.C., Gosline, J.M., 1997. Strategies for life in flow: tenacity, morphometry, and probability of dislodgment of two Mytilus species. Mar. Ecol. Prog. Ser. 159, 197-208.

Bioplastics Europe, 2016. Bioplastics - facts and figures. http://www.europeanbioplastics.org.

Brigelius-Flohé, R., Maiorino, M., 2013. Glutathione peroxidases. Biochim. Biophys. Acta 1830 (5), 3289-3303.

Brown, R.T., Galloway, T.S., Lowe, D., Browne, M.A. Dissanayake, A., Jones, M.B. Depledge, M.H., 2006. Differential sensitivity of three marine invertebrates to copper assessed using multiple biomarkers. Aquat. Toxicol. 66 (3), 267-278.

Browne, M.A., Dissanayake, A., Galloway, T.S., Lowe, D.M., Thompson, R.C., 2008. Ingested microscopic plastic translocates to the circulatory system of the mussel, Mytilus edulis (L.). Environ. Sci. Technol. 42 (13), 5026-5031.

Campos, A., Apraiz, I., da Fonseca, R.R., Cristobal, S., 2015. Shotgun analysis of the marine mussel Mytilus edulis hemolymph proteome and mapping the innate immunity elements. Proteomics 15 (23-24), 4021-4029.

Campos, A., Danielsson, G., Farinha, A.P., Kuruvilla, J., Warholm, P., Cristobal, S., 2016. Shotgun proteomics to unravel marine mussel (Mytilus edulis) response to longterm exposure to low salinity and propranolol in a Baltic Sea microcosm. Journal of proteomics 137, 97-106.

Carballal, M.J., Lopez, C., Azevedo, C., Villalba, A., 1997. Enzymes involved in defense functions of hemocytes of mussel Mytilus galloprovincialis. J. Invertebr. Pathol. 70 (2), 96-105.

Carrington, E., 2002. Seasonal variation in the attachment strength of blue mussels: causes and consequences. Limnol. Oceanogr. 47 (6), 1723-1733.

Christensen, H.T., Dolmer, P., Hansen, B.W., Holmer, M., 2015. Aggregation and attachment responses of blue mussels, Mytilus edulis-impact of substrate composition, time scale and source of mussel seed. Aquaculture 435, 245-251. 
Coles, J.A., Farley, S.R., Pipe, R.K., 1995. Alteration of the immune response of the common marine mussel Mytilus edulis resulting from exposure to cadmium. Dis. Aquat. Org. 22, 59-65.

Conesa, A., Gotz, S., Garcia-Gomez, J.M., Terol, J., Talon, M., Robles, M., 2005 Blast2GO: a universal tool for annotation, visualization and analysis in functional genomics research. Bioinformatics 21 (18), 3674-3676.

Cox, J., Neuhauser, N., Michalski, A., Scheltema, R.A., Olsen, J.V., Mann, M., 2011 Andromeda: a peptide search engine integrated into the MaxQuant environment. J. Proteome Res. 10 (4), 1794-1805.

Cox, J., Hein, M.Y., Luber, C.A., Paron, I., Nagaraj, N., Mann, M., 2014. Accurate proteome-wide label-free quantification by delayed normalization and maximal peptide ratio extraction, termed MaxLFQ. Mol. Cell. Proteomics 13 (9), 2513-2526.

de Sá, L.C., Oliveira, M., Ribeiro, F., Rocha, T.L., Futter, M.N., 2018. Studies of the effects of microplastics on aquatic organisms: what do we know and where should we focus our efforts in the future? Sci. Total Environ. 645, 1029-1039.

De Witte, B., Devriese, L., Bekaert, K., Hoffman, S., Vandermeersch, G., Cooreman, K. Robbens, J., 2014. Quality assessment of the blue mussel (Mytilus edulis) comparison between commercial and wild types (Translated from English) Mar. Pollut. Bull. 85 (1), 146-155.

Denny, M.W., 1987. Lift as a mechanism of patch initiation in mussel beds. J. Exp. Mar. Biol. Ecol. 113 (3), 231-245.

Eriksen, M., Lebreton, L.C.M., Carson, H.S., Thiel, M., Moore, C.J., Borerro, J.C., Galgani, F., Ryan, P.G., Reisser, J., 2014. Plastic pollution in the world's oceans: more than 5 trillion plastic pieces weighing over 250,000 tons afloat at sea. PLoS One 9 (12)

Espinosa, C., Beltran, J.M.G., Esteban, M.A., Cuesta, A., 2018. In vitro effects of virgin microplastics on fish head-kidney leucocyte activities. Environ. Pollut. 235, 30-38.

Estevez-Calvar, N., Romero, A., Figueras, A., Novoa, B., 2011. Involvement of poreforming molecules in immune defense and development of the Mediterranean mussel (Mytilus galloprovincialis). Dev. Comp. Immunol. 35 (10), 1015-1029.

FAO yearbook, 2015. Fishery and Aquaculture Statistics (Rome, Italy).

Fields, P.A., Zuzow, M.J., Tomanek, L., 2012. Proteomic responses of blue musse (Mytilus) congeners to temperature acclimation. J. Exp. Biol. 215, 1106-1116.

Fox, J., Weisberg, S., 2011. An $\{\mathrm{R}\}$ Companion to Applied Regression, second ed. Sage http://socserv.socsci.mcmaster.ca/jfox/Books/Companion.

Galgani, F., Hanke, G., Maes, T., 2015. Global distribution, composition and abundance of marine litter. In: Bergmann, M., Gutow, L., Klages, M. (Eds.), Marine Anthropogenic Litter. Springer International Publishing, Cham), pp. 29-56.

Galloway, T.S., Cole, M., Lewis, C., 2017. Interactions of microplastic debris throughout the marine ecosystem. Nat. Ecol. Evol. 1, 0116.

Gerdol, M., Manfrin, C., De Moro, G., Figueras, A., Novoa, B., Venier, P., Palavicini, A., 2011. The C1q domain containing proteins of the Mediterranean mussel Mytilus galloprovincialis: a widespread and diverse family of immune-related molecules. Dev. Comp. Immunol. 35 (6), 635-643.

Gestal, C., Pallavicini, A., Venier, P., Novoa, B., Figueras, A., 2010. MgC1q, a novel C1qdomain-containing protein involved in the immune response of Mytilus galloprovincialis. Dev. Comp. Immunol. 34 (9), 926-934.

Gomes, T., Pereira, C.G., Cardoso, C., Bebianno, M.J., 2013. Differential protein expression in mussels Mytilus galloprovincialis exposed to nano and ionic Ag. Aquat. Toxicol. 136, 79-90.

Green, D.S., 2016. Effects of microplastics on European flat oysters, Ostrea edulis and their associated benthic communities. Environ. Pollut. 216, 95-103.

Green, D.S., Boots, B., Sigwart, J., Jiang, S., Rocha, C., 2016. Effects of conventional and biodegradable microplastics on a marine ecosystem engineer (Arenicola marina) and sediment nutrient cycling. Environ. Pollut. 208, 426-434.

Green, D.S., Boots, B., O'Connor, N.E., Thompson, R.C., 2017. Microplastics affect the ecological functioning of an important biogenic habitat. Environ. Sci. Technol. 51 (1), 68-77.

Hall, T.A., 1999. BioEdit: a user-friendly biological sequence alignment editor and analysis program for Windows 95/98/NT. Nucleic Acids Symp. Ser. 41, 95-98.

Hannam, M.L., Bamber, S.D., Galloway, T.S., Moody, A.J., Jones, M.B., 2010. Effects of the model PAH phenanthrene on immune function and oxidative stress in the haemolymph of the temperate scallop Pecten maximus. Chemosphere 78 (7) $779-784$.

Huang, Y., Niu, B., Gao, Y., Fu, L., Li, W., 2010. CD-HIT Suite: a web server for clustering and comparing biological sequences. Bioinformatics 26 (5), 680-682.

Hubner, N.C., Bird, A.W., Cox, J., Splettstoesser, B., Bandilla, P., Poser, I., 2010. Quantitative proteomics combined with BAC TransgeneOmics reveals in vivo protein interactions. JCB (J. Cell Biol.) 189 (4), 739-754.

IPCC, 2014. Climate Change 2014: Impacts, Adaptation, and Vulnerability. Part A: Global and Sectoral Aspects. Contribution of Working Group II to the Fifth Assessment Report of the Intergovernmental Panel on Climate Change. Cambridge University Press, Cambridge.

Jambeck, J.R., Geyer, R., Wilcox, C., Siegler, T.R., Perryman, M., Andrady, A., Narayan, R., Lavender Law, K., 2015. Plastic waste inputs from land into the ocean. Science 347 (6223), 768-771.

Jeong, C.B., Kang, H.M., Lee, M.C., Kim, D.H., Han, J., Hwang, D.S., Souissi, S., Lee, S.J., Shin, K.H., Heum, G.P., Lee, J.S., 2017. Adverse effects of microplastics and oxidative stress-induced MAPK/Nrf2 pathway-mediated defense mechanisms in the marine copepod Paracyclopina nana. Sci. Rep. 7, 41323.

Lei, L., Liu, M., Song, Y., Lu, S., Hu, J., Cao, C., Xie, B., Shic, H., He, D., 2018. Polystyrene (nano)microplastics cause size-dependent neurotoxicity, oxidative damage and other adverse effects in Caenorhabditis elegans. Environ. Sci.: Nano 5, 2009-2020.

Lenz, R., Enders, K., Nielsen, T.G., 2016. Microplastic exposure studies should be environmentally realistic. Proc. Natl. Acad. Sci. Unit. States Am. 113 (29), E4121-E4122.

Liu, H.H., Xiang, L.X., Shao, J.Z., 2014. A novel C1q-domain-containing (C1qDC) protein from Mytilus coruscus with the transcriptional analysis against marine pathogens and heavy metals. Dev. Comp. Immunol. 44 (1), 70-75.

Malagoli, D., Casarini, L., Sacchi, S., Ottaviani, E., 2007. Stress and immune response in the mussel Mytilus galloprovincialis. Fish Shellfish Immunol. 23 (1), 171-177.

Mann, K., Edsinger, E., 2014. The Lottia gigantea shell matrix proteome: re-analysis including MaxQuant iBAQ quantitation and phosphoproteome analysis. Proteome Sci. 12 (1), 28.

Mann, K., Edsinger-Gonzales, E., Mann, M., 2012. In-depth proteomic analysis of a mollusc shell: acid-soluble and acid-insoluble matrix of the limpet Lottia gigantea. Proteome Sci. 10 (1), 28.

Markets and Markets, 2015. Biodegradable plastics market by type (PLA, PHA, PBS, starch-based plastics, regenerated cellulose, PCL), by application (packaging, fibers, agriculture, injection molding, and others) - global trends \& forecasts to 2020. Accessed 12/05/18, http://www marketsandmarkets.com.

McNamara, L.M., Carolan, J.C., Griffin, C.T., Fitzpatrick, D., Kavanagh, K., 2017. The effect of entomopathogenic fungal culture filtrate on the immune response of the greater wax moth. Galleria mellonella J. Insect Physiol. 100, 82-92.

Mejáre, M., Bülow, L., 2001. Metal-binding proteins and peptides in bioremediation and phytoremediation of heavy metals. Trends Biotechnol. 19 (2), 67-73.

Miko, Z., Ujszegi, J., Gal, Z., Imrei, Z., Hettyey, A., 2015. Choice of experimental venue matters in ecotoxicology studies: comparison of a laboratory-based and an outdoor mesocosm experiment. Aquat. Toxicol. 167, 20-30.

Mitta, G., Hubert, F., Noël, T., Roch, P., 1999. Myticin, a novel cysteine-rich antimicrobial peptide isolated from haemocytes and plasma of the mussel Mytilus galloprovincialis. Eur. J. Biochem. 265 (1), 71-78.

Murgarella, M., Puiu, D., Novoa, B., Figueras, A., Posada, D., Canchaya, C., 2016. A first insight into the genome of the filter-feeder mussel Mytilus galloprovincialis. PLoS One 11 (3), e0151561.

O'Donnell, M.J., George, M.N., Carrington, E., 2013. Mussel byssus attachment weakened by ocean acidification. Nat. Clim. Change 3 (6), 587-590.

Paul-Pont, I., Lacroix, C., González Fernández, C., Hégaret, H., Lambert, C., Le Goïc, N. Frère, L., Cassone, A.L., Sussarellu, R., Fabioux, C., Guyomarch, J., Albentosa, M. Huvet, A., Soudant, P., 2016. Exposure of marine mussels Mytilus spp. to polystyrene microplastics: toxicity and influence on fluoranthene bioaccumulation. Environ. Pollut. 216, 724-737.

Plastics Europe, 2017. Plastics - the facts 2017. An analysis of European plastics production, demand and waste data. http://www.plasticseurope.org.

Qin, X., Waite, J.H., 1995. Exotic collagen gradients in the byssus of the mussel Mytilus edulis. J. Exp. Biol. 198 (3), 633-644.

Qin, C.L., Pan, Q.D., Qi, Q., Fan, M., Sun, J.J., Li, N., Liao, Z., 2016. In-depth proteomic analysis of the byssus from marine mussel Mytilus coruscus. Journal of proteomics 144, 87-98.

Renwrantz, L., Werner, I., 2007. Origin of a metal-binding protein in serum of Mytilus edulis. J. Molluscan Stud. 74 (1), 11-17.

Romero, A., Dios, S., Poisa-Beiroa, L., Costa, M.M., Posad, D., Figueras, A., Novoa, B., 2011. Individual sequence variability and functional activities of fibrinogenrelated proteins (FREPs) in the Mediterranean mussel (Mytilus galloprovincialis) suggest ancient and complex immune recognition models in invertebrates. Dev. Comp. Immunol. 35 (3), 334-344.

Seed, R., 1996. Patterns of biodiversity in the macro-invertebrate fauna associated with mussel patches on rocky shores. J. Mar. Biol. Assoc. U. K. 76 (1), 203-210.

Sellami, B., Khazri, Louati, H., Della, M., Ridha, M., Driss, M., Aïssa, P., Mahmoudi, E., Hamouda, B., Coelho, A.V., Sheehan, D., 2015. Effects of anthracene on filtration rates, antioxidant defense system, and redox proteomics in the Mediterranean clam Ruditapes decussatus (Mollusca: Bivalvia). Environ. Sci. Pollut. Control Ser. 22 (14), 10956-10968.

Sussarellu, R., Suquet, M., Thomas, Y., Lambert, C., Fabioux, C., Pernet, M.E.J., Le Goïc, N., Quillien, V., Mingant, C., Epelboion, Y., Corporeau, C., Guyomarch, J., Robbens, J., PaulPont, I., Soudant, P., Huvet, A., 2016. Oyster reproduction is affected by exposure to polystyrene microplastics. Proc. Natl. Acad. Sci. Unit. States Am. 113, 2430-2435.

Tomanek, L., 2012. Environmental proteomics of the mussel Mytilus: implications for tolerance to stress and change in limits of biogeographic ranges in response to climate change. Integr. Comp. Biol. 52 (5), 648-664.

Tomanek, L., 2014. Proteomics to study adaptations in marine organisms to environmental stress. Journal of proteomics 105, 92-106.

Tomanek, L., 2015. Proteomic responses to environmentally induced oxidative stress. J. Exp. Biol. 218 (12), 1867-1879.

Van Cauwenberghe, L., Claessens, M., Vandegehuchte, M.B., Janssen, C.R., 2015. Microplastics are taken up by mussels (Mytilus edulis) and lugworms (Arenicola marina) living in natural habitats. Environ. Pollut. 199, 10-17.

Vasta, G.R., Feng, C., Bianchet, M.A., Bachvaroff, T.R., Tasumi, S., 2015. Structural, functional, and evolutionary aspects of galectins in aquatic mollusks: from a sweet tooth to the Trojan horse. Fish Shellfish Immunol. 46 (1), 94-106.

Vidal-Liñán, L., Bellas, J., Salgueiro-González, N., Muniategui, S., Beiras, R., 2015. Bioaccumulation of 4-nonylphenol and effects on biomarkers, acetylcholinesterase, glutathione-S-transferase and glutathione peroxidase, in Mytilus galloprovincialis mussel gills. Environ. Pollut. 200, 133-139.

Vizcaíno, J.A., Csordas, A., del-Toro, N., Dianes, J.A., Griss, J., Lavidas, I., Mayer, G., 
Perez-Riverol, Y., Reisinger, F., Ternent, T., Xu, Q.W., Wang, R., Hermjakob, H., 2016. 2016 update of the PRIDE database and related tools. Nucleic Acids Res. 44 (D1), D447-D456.

von Moos, N., Burkhardt-Holm, P., Koehler, A., 2012. Uptake and effects of microplastics on cells and tissue of the blue mussel Mytilus edulis L. After an experimental exposure. Environ. Sci. Technol. 46 (20), 11327-11335.

Waite, J.H., 1991. Mussel Beards - a coming of age. Chem. Ind. (17), 607-611.

Wu, H., Xu, L., Ji, C., Yu, D., 2016. Proteomic and metabolomic responses in D-shape larval mussels Mytilus galloprovincialis exposed to cadmium and arsenic. Fish Shellfish Immunol. 58, 514-520.

Yamada, A., Yoshio, M., Oiwa, K., Nyitray, L., 2000. Catchin, a novel protein in molluscan catch muscles, is produced by alternative splicing from the myosin heavy chain gene. (Translated from English). J. Mol. Biol. 295 (2), 169-178.

Zhao, X., Guo, C., Han, Y., Che, Z., 2017. Ocean acidification decreases mussel byssal attachment strength and induces molecular byssal responses. Mar. Ecol. Prog. Ser. 565, 67-77. 